\title{
Przegląd teorii finansów gospodarstw domowych w kontekście współczesnych uwarunkowań polityki publicznej
}

\begin{abstract}
Streszczenie
Celem artykułu jest syntetyczna prezentacja teorii finansów gospodarstw domowych w obszarze ekonomii, socjologii oraz psychologii. Przegląd teorii, niezależnie od dziedziny nauki, pokazuje na postępujący wzrost złożoności oraz indywidualizacji finansów gospodarstw domowych. Jednocześnie rozszerzeniu uległ zakres badań (o aspekty socjologiczne i psychologiczne decyzji podejmowanych przez i w ramach gospodarstwa domowego), co przyczynia się znacząco do lepszego odwzorowania rzeczywistości w teoriach ekonomicznych. Rozwój koncepcji dotyczących funkcjonowania gospodarstw domowych wskazuje wyraźnie na rosnące znaczenie ich finansów. Nie oznacza to bynajmniej zmniejszenia roli polityki publicznej w zakresie zapewnienia bezpieczeństwa ekonomicznego gospodarstw domowych. Wręcz przeciwnie, rosnąca finansjalizacja budżetów gospodarstw domowych stawia przed polityką publiczną nowe wyzwania. Stan budżetów gospodarstw domowych coraz silniej oddziałuje na ogólną sytuację gospodarczą, a dla osiągnięcia założonego poziomu skuteczności wymagana jest większa precyzja w konstrukcji rozwiązań publicznych.
\end{abstract}

Słowa kluczowe: finanse gospodarstw domowych, polityka publiczna, cykle życia.

\section{An overview of the household finances theories in the light of contemporary public policy}

\begin{abstract}
The aim of this paper is a synthetic presentation of the theory of household finances in the area of economics, sociology and psychology. An overview of the theories, regardless of the field of science, shows a progressive increase in the complexity and individualisation of household finances. At the same time the extension of the scope of the research (of sociological and psychological aspects of decisions made by and within a household)
\end{abstract}


has contributed significantly to a better representation of reality in economic theories. The development of the concept regarding the functioning of households clearly shows the growing importance of household finances. This does not mean reducing the role of public policy in ensuring the economic security of households. On the contrary, the growing financialisation of household budgets poses new challenges to public policy. The condition of household budgets increasingly affects the overall economy and in order to achieve the target level of effectiveness, greater precision in the design of public solutions is required.

Keywords: household finances, public policy, life cycles.

Ekonomia, wywodząca nazwę od gospodarstwa domowego, w sposób oczywisty swoim zainteresowaniem obejmuje również finanse gospodarstw domowych. Jednak początkowo zainteresowanie to było związane $\mathrm{z}$ agregatowymi wartościami przychodów, konsumpcji i oszczędności ${ }^{1}$. Obie kategorie wynikowe, tj. konsumpcja i oszczędności, w sposób istotny wpływają na gospodarkę i są traktowane jako agregaty do modeli makroekonomicznych. Jednocześnie zagadnienie przychodów i konsumpcji ${ }^{2}$ można analizować na poziomie mikro (pojedynczego gospodarstwa domowego). W obu wypadkach jest to obszar zainteresowania polityki publicznej, tutaj rozumianej jako „całokształt decyzji, czynności oraz działań organizatorskich i wykonawczych podejmowanych przez władzę publiczną (w jej imieniu oraz przez różne podmioty publiczne i prywatne), zmierzających do osiągnięcia zdefiniowanych celów rozwojowych na różnych szczeblach państwa, korzystnych ze względu na obowiązek państwa związany z tworzeniem optymalnych warunków rozwoju cywilizacyjnego danego społeczeństwa”’3. Zainteresowanie to wzmaga się z uwagi na: rosnącą komplikację procesów społecznych i gospodarczych, zwiększający się zakres finansjalizacji budżetów gospodarstw domowych, rosnące zróżnicowanie gospodarstw domowych oraz większe oczekiwania odnośnie do polityki publicznej

Pierwsze teorie ekonomiczne próbowały ująć relacje między przychodami a konsumpcją w sposób zdroworozsądkowy i na podstawie obserwacji bieżących zachowań

1 Co ciekawe, teorie tworzące główny nurt charakteryzują się podejściem mikroekonomicznym.

2 Przychody i konsumpcja to kategorie finansów gospodarstw domowych najczęściej analizowane w badaniach ekonomicznych. Oczywiście samo pojęcie finansów gospodarstw domowych jest szersze. Więcej patrz: M. Kawiński, Ubezpieczenie społeczne a finanse osobiste, w: Doubezpieczenie społeczne - idea i kontynuacja, red. M. Kawiński, Oficyna Wydawnicza SGH, Warszawa 2015, s. 33-39.

3 J. Osiński, Wstęp, w: Polityka publiczna we współczesnym państwie, red. J. Osiński, Oficyna Wydawnicza SGH, Warszawa 2014, s. 7.

4 Głównie w kontekście jakościowym, tj. skuteczności w identyfikacji i rozwiązywaniu problemów społecznych. 
opisać standardowe zachowania gospodarstw domowych. Dotyczy to szczególnie koncepcji autorstwa J.M. Keynesa. Teoria Keynesa była o tyle istotna, że zaproponowała jednoznaczne określenie relacji przychodów i konsumpcji, tzn. wraz ze wzrostem konsumpcji maleje udział konsumpcji (average propensity to consume), gdyż maleje marginalna skłonność do konsumpcji (marginal propensity to consume) ${ }^{5}$. Nie mniejszą zasługą teorii Keynesa było przyczynienie się do licznych badań weryfikujących jej założenia.

W tym miejscu należy przywołać prace S. Kuznetsa oraz R. Godsmitha, którzy na podstawie danych empirycznych próbowali zweryfikować teorię Keynesa ${ }^{6}$. Ich badania wskazały, że w dłuższym okresie udział konsumpcji w przychodach był niezmienny mimo wzrostu przychodów. Z kolei porównanie gospodarstw między sobą albo analiza krótkich szeregów czasowych potwierdzały koncepcję o malejącej skłonności do konsumpcji wraz z przyrostem przychodów. Ta niekonsekwencja, tzw. paradoks Kuznetsa, stała się przyczynkiem do kolejnych teorii, które próbowały wytłumaczyć skomplikowane relacje konsumpcji i przychodów.

W roku 1949 J. Duesenberry przedstawił hipotezę relatywnego przychodu, w której model został sformułowany w dwóch wariantach, odnoszących się wprost do dokonanego przez Kuznetsa porównania gospodarstw między sobą oraz analizy szeregów czasowych ${ }^{7}$. Duesenberry argumentował, że konsumpcja gospodarstw domowych nie jest przedmiotem racjonalnego planowania oraz wynika $\mathrm{z}$ uczenia i naśladownictwa zwyczajów grupy odniesienia, tj. gospodarstw domowych uznawanych za egzemplifikację określonego typu, których model konsumpcji staje się wzorem dla innych ${ }^{8}$. Według tej hipotezy dla gospodarstwa domowego istotny jest

5 Podobne twierdzenie sformułował I. Fisher, The rate of interest. Its nature, determination and relations to economic phenomena, The MacMillian Company, New York 1907, s. 94-95. Warto zauważyć, że oryginalna funkcja konsumpcji określona przez Keynesa miała postać: $\mathrm{C}=\mathrm{c}(\mathrm{Y}), \mathrm{C}-$ konsumpcja, Y - przychód, c - wskaźnik udziału konsumpcji w przychodzie, J.M. Keynes, The General Theory of Employment, Interest and Money, Harcourt, Brace Company, New York 1937, s. 90. Interpretacja późniejszego opisu konsumpcji (Ibidem, s. 96), doprowadziła do formuły: $C=\alpha_{0}+\alpha_{1} Y, \alpha_{0}-$ początkowa wartość aktywów, $\alpha_{1}$ - wskaźnik krańcowej skłonności do konsumpcji w bieżącym przychodzie, obecnie uznawanej za standardową. Z czasem zaproponowano również rozwinięcie tej funkcji dla gospodarstw zamożniejszych, w których przychody z aktywów $\left(\mathrm{Y}_{2}\right)$, obok przychodów z pracy $\left(\mathrm{Y}_{1}\right)$, nabierają istotnego znaczenia: $\mathrm{C}=\mathrm{a}_{0}+\mathrm{a}_{1} \mathrm{Y}_{1}+\mathrm{a}_{2} \mathrm{Y}_{2}$. A. Ando, F. Modigliani, The "Life Cycle" Hypothesis of Saving: Aggregate Implications and Tests, "American Economic Review", vol. 53, no. 1, part 1, March 1963, s. 55-84.

6 S. Kuznets, Uses of National Income in Peace and War, NBER, March 1942; R. W. Goldsmith, A study on saving in the United States, Princeton University Press, New Jersey 1955. Badania Kuznetsa były oparte na amerykańskich danych z drugiej połowy XIX w. oraz pierwszej połowy XX w.

7 J. Duesenberry, Income, Saving and the Theory of Consumption Behavior, Harvard University Press, Cambridge 1949.

8 Obecnie w sytuacji rozwoju mediów oraz ich wpływu na życie i zachowania członków gospodarstw domowych może to być również powszechne wyobrażenie o modelowej konsumpcji charakterystycznej dla określonej grupy gospodarstw domowych, prezentowane np. w serialach telewizyjnych. Dlatego niezmiernie istotne jest, skąd dane wzorce są dostępne i jak można na nie wpływać. 
punkt odniesienia, którym jest poziom i struktura konsumpcji grupy, do jakiej aspiruje dane gospodarstwo domowe. W takiej sytuacji różnice w przychodach określonej grupy społecznej mogą się okazać większe niż konsumpcji (np. poziom życia klasy średniej), tzw. efekt demonstracyjny (pokazowy) ${ }^{9}$. W analizie szeregów czasowych dla danego gospodarstwa domowego kluczowe są okresy najwyższego poziomu przychodów, które z uwagi na moc oddziaływania przyzwyczajenia determinują poziom konsumpcji, nawet w sytuacji spadku przychodów ${ }^{10}$. Jednocześnie z ograniczeniem od dołu, którym jest minimalny poziom wydatków konsumpcyjnych, powstaje również ograniczenie $z$ góry, tj. maksymalny poziom wydatków ${ }^{11}$. Górne ograniczenie może być zniesione, gdy naśladowane gospodarstwa domowe w sposób widoczny zwiększą poziom wydatków.

Badania empiryczne pokazały, że zależności między przychodami i wydatkami są zmienne z uwagi na stopień elastyczności konsumpcji w relacji do przychodów oraz okresy nierównowagi między przychodami i konsumpcją. To oznacza, że standardowo konsumpcja rośnie w stałym tempie, proporcjonalnie do wzrostu przychodów, jednak w momencie wystąpienia recesji konsumpcja opada wolniej aniżeli przychody. W praktyce może dochodzić wręcz do tzw. efektu rygla konsumpcyjnego, gdy przez pewien okres konsumpcja pozostaje na niezmienionym poziomie, mimo obniżenia przychodów ${ }^{12}$. W konsekwencji może to prowadzić do sytuacji, gdy przejściowo przychody są niższe od konsumpcji i wykorzystywane są oszczędności albo inne aktywa. W razie odwrócenia trendu konsumpcja rośnie wolniej niż przychody, aż do osiągnięcia poprzedniego poziomu przychodów, wówczas konsumpcja zaczyna przyrastać w tym samym tempie, co przychody. Stąd znajomość zależności między przychodami i wydatkami jest bardzo istotna dla realizacji polityki publicznej.

Należy podkreślić, że teoria Duesenberry’ego uwzględniła czynniki psychologiczne związane z formowaniem zwyczajów konsumpcyjnych oraz społeczne współzależności wpływające na relatywność przychodów. Tym samym różniła się w sposób

9 Cz. Bywalec, Ekonomia i finanse gospodarstw domowych, Wydawnictwo Naukowe PWN, Warszawa 2012, s. 68.

${ }^{10}$ Hipoteza Duesenberry’ego, choć popularna w latach 50. i 60., przez długi okres nie była używana z uwagi na założenie dotyczące braku niezależności między analizowanymi decyzjami gospodarstw domowych, co znacząco utrudnia zastosowanie funkcji użyteczności oraz podważa jedno z podstawowych założeń w ekonomii odnośnie do racjonalności zachowań. Więcej na temat potencjalnych przyczyn patrz: T.I. Palley, Relative Income and Consumption: A Synthesis of Keynes, Duesenberry, Friedman, and Modigliani and Brumbergh, July 2005. Obecnie hipoteza ta ponownie zyskuje na znaczeniu dzięki aplikacji sposobu identyfikacji jednostki do analizy ekonomicznej (A. Akerlof, R.E. Kranton, Economics and identity, "The Quarterly Journal of Economics" 2000, vol. CXV, issue 3, s. 715-753) oraz włączenia zwyczajów naśladownictwa do funkcji użyteczności (J.C. Fuhrer, Habit Formation in Consumption and Its Implications for Monetary-Policy Models, "American Economic Review" 2000, vol. 90, no. 3, s. 367-390).

${ }^{11}$ J. Duesenberry, op.cit., s. 26.

${ }_{12} \mathrm{Cz}$. Bywalec, op.cit., s. 68. 
zasadniczy od teorii opartych na koncepcji racjonalności zachowań ludzkich, tj. hipotezy permanentnego przychodu oraz koncepcji cykli życia (life-cyle theory) ${ }^{13}$. Obie teorie, wychodząc z perspektywy mikroekonomicznej, uniezależniają konsumpcję od bieżącego przychodu, zamiast tego wprowadzając relacje między konsumpcją a całkowitymi (spodziewanymi) zasobami oraz zdyskontowanymi (permanentnymi) przychodami i opierają teorie na maksymalizacji użyteczności konsumpcji w nieskończoności (hipoteza permanentnego przychodu) albo w określonym czasie (wyrażonym jako przeciętne dalsze trwanie życia w koncepcji cykli życia).

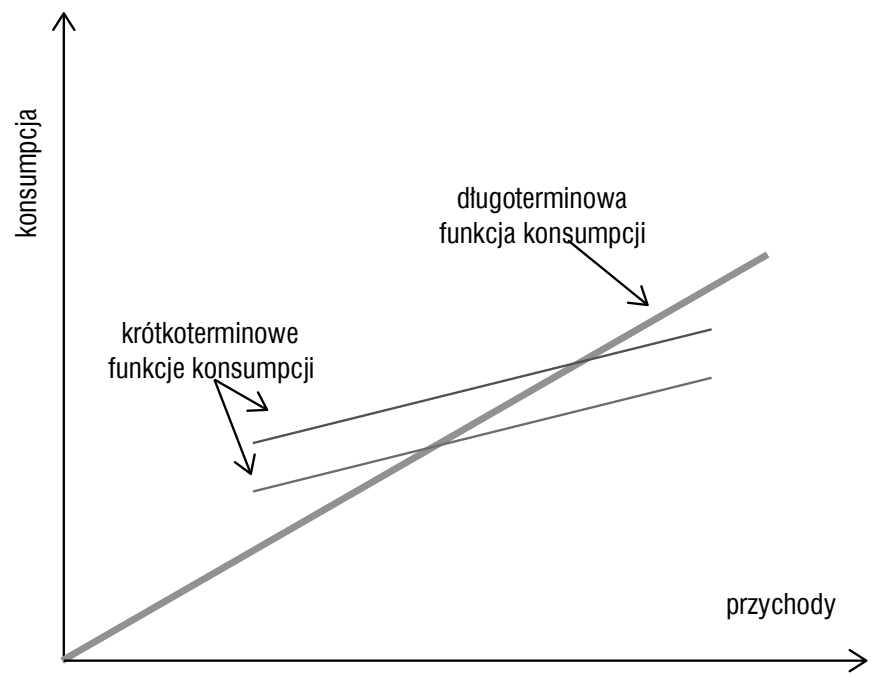

\section{Rysunek 1. Krótkoterminowe i długoterminowe funkcje konsumpcji}

Źródło: J. Parker, Economics coursebook: macroeconomics theory, Reed College, Spring 2015, s. 16-5, http:// academic.reed.edu/economics/parker/314/index.html

Zagadnienie intertemporalnej optymalizacji pojawiło się już wcześniej, np. w pracy I. Fishera, który uzależniał przenoszenie konsumpcji między okresami od wysokości, rozłożenia w czasie i przewidywalności przychodów, horyzontu czasowego podejmowania decyzji, zdolności do wyrzeczenia się bieżącej konsumpcji, chęci pozostawienia spadku oraz stopy zwrotu $^{14}$. Na uwagę zasługuje również koncepcja

${ }^{13} \mathrm{Na}$ uwagę zasługuje fakt, że M. Friedman nie znajdował podstaw do odrzucenia hipotezy relatywnego przychodu, aczkolwiek był przekonany o „wyższości” własnej hipotezy, M. Friedman, A Theory of the Consumption Function, Princeton University Press, New Jersey 1957, s. 169.

${ }^{14}$ I. Fisher, The rate of interest. Its nature, determination and relations to economic phenomena, The MacMillian Company, New York 1907, s. 87-116. 
zaprezentowana przez F. Ramsey’a, która charakteryzuje się, tak jak o wiele lepiej znany model M. Friedmana, nieograniczonym horyzontem czasowym ${ }^{15}$.

Koncepcja M. Friedmana oparta była na kategorii przychodów permanentnych (stałych), które są wyobrażeniem co do przyszłych przychodów i zasobów. Wyobrażenie o spodziewanych przychodach zależy od zasobów materialnych, zdolności, aktywności ekonomicznej i może być interpretowane jako wartość oczekiwana rozkładu prawdopodobieństwa ${ }^{16}$. Modyfikacja relacji wydatków konsumpcyjnych oraz oszczędności do dochodu może być wywołana poprzez: zmiany poziomu stopy procentowej (wyższe stopy zwiększają oszczędności kosztem konsumpcji), zmiany relacji majątku do przychodu (wyższa relacja majątku do przychodów zwiększa konsumpcję), nagłe i znaczące zmiany poziomu cen dóbr konsumpcyjnych (efekt substytucyjny, cenowy i dochodowy), zmiany stopnia niepewności (wzrost niepewności zmniejsza bieżące wydatki konsumpcyjne), wiek i stan rodzinny (różnice indywidualne), uwarunkowania kulturowo-społeczne (tradycje, wykształcenie, efekt pokazowy i inne - różnice indywidualne $)^{17}$. Jednak konkretna wartość przychodów permanentnych jest trudna do bieżącego pomiaru i opiera się na analizie danych historycznych ${ }^{18}$. Dlatego jej przydatność dla polityki publicznej jest ograniczona.

Przychody permanentne wraz z przychodami przejściowymi (chwilowymi) tworzą obserwowane przychody rozporządzalne. Konsumenci dostosowują konsumpcję do zmian przychodów permanentnych, ale w większości wypadków ignorują zmiany w przychodzie przejściowym. Według Friedmana u osób o wyższym poziomie przychodów rozporządzalnych przychody przejściowe stanowią większą część niż przeciętnie, dlatego nie jest racjonalne zwiększanie konsumpcji proporcjonalnie do zmian przychodów rozporządzalnych. W razie istotnego spadku przychodów rozporządzalnych poniżej przychodów permanentnych zakłada się możliwość wzięcia pożyczki. Przy okazji Friedman zauważa, że stopa procentowa może być różna w zależności, czy jej „zabezpieczenie” stanowią środki trwałe, czy też przyszłe przychody ${ }^{19}$.

Należy jednocześnie zauważyć, że choć hipoteza Friedmana nie odnosi zmian przychodów i konsumpcji do wieku i faz cyklu życia ${ }^{20}$, to jednak poziom przychodów permanentnych, determinujący poziom konsumpcji, uwzględnia spodziewane

15 F.P. Ramsey, A Mathematical Theory of Saving, "The Economic Journal” 1928, vol. 38, no. 152, s. 543-559.

16 Tym samym Friedman uwzględnił element niepewności, M. Friedman, A Theory of the Consumption Function, Princeton University Press, New Jersey 1957, s. 21.

${ }_{17}$ Cz. Bywalec, op.cit., s. 64.

${ }_{18}$ M. Friedman, op.cit., s. 20.

${ }^{19}$ Jednak w swojej końcowej hipotezie Friedman rezygnuje z tego rozróżnienia. Warto na marginesie zauważyć, że zasoby (środki trwałe), nabyte czy też dziedziczone, odgrywają bardzo ważną rolę w koncepcji Friedmana, zarówno jako źródło przychodów, jak i zabezpieczenie ewentualnych pożyczek. Ibidem, s. 16.

${ }^{20}$ Cz. Bywalec, op.cit., s. 63. 
przyszłe przychody oraz może być modyfikowany wraz z wiekiem i przebiegiem przychodów rozporządzalnych w czasie ${ }^{21}$. Natomiast teoria cykli życia wprost zakłada ograniczony okres funkcjonowania gospodarstwa domowego i rozpatruje jego zasoby oraz konsumpcję w poszczególnych fazach cyklu życia. Pierwsza wersja hipotezy jest autorstwa F. Modiglianiego oraz R. Brumberga ${ }^{22}$. Kolejny wariant powstał jako efekt współpracy F. Modiglianiego z A. Ando ${ }^{23}$.

Pierwotnie zidentyfikowano dwie fazy - okres aktywności zawodowej i okres emerytalny, w późniejszych modelach zakładano trzy fazy, tj. okres nauki, aktywności zawodowej, emerytalny. Na zasoby gospodarstwa domowego składają się jego przychody z pracy ${ }^{24}$. Poziom przychodów, co oczywiste, różni się między fazami, ale też istotne fluktuacje mogą nastąpić w ramach poszczególnych faz. Najczęściej zakłada się tutaj charakterystyczny przyrost przychodów w trakcie aktywności zawodowej, tak że są one największe tuż przed przejściem na emeryturę ${ }^{25}$. Oprócz przychodów do zasobów zalicza się aktywa, które ma w swoim posiadaniu gospodarstwo domowe ${ }^{26}$.

Głównym założeniem hipotezy cykli życia jest dążenie do maksymalizacji krańcowej użyteczności konsumpcji w kontekście pozostałego okresu życia, tj. przychodów, wydatków i zasobów. W konsekwencji wydatki konsumpcyjne są niezależne od bieżących przychodów oraz występuje zjawisko wygładzania konsumpcji w czasie, tj. brak gwałtownych spadków i wzrostów konsumpcji na skutek impulsów przychodowych. Wygładzanie konsumpcji może się odbywać poprzez pożyczki oraz rozwiązywanie oszczędności. Z uwagi na relacje wydatków konsumpcyjnych i przychody, zadłużanie jest szczególnie uzasadnione w pierwszej fazie. Natomiast nadwyżka w drugiej fazie powinna być wykorzystywana do kumulacji oszczędności w trzeciej fazie. Podobnie jak u Friedmana, w drugiej fazie gospodarstwo domowe kumuluje nadwyżki, ale zaznaczony jest cel emerytalny akumulacji oszczędności i zasobów oraz brak uwzględnienia spadków. Oznacza to, że nawet w wypadku dóbr trwałych, takich jak zasoby mieszkaniowe, hipoteza cykli życia zakłada ich dekumulację w ostatniej fazie ${ }^{27}$.

${ }^{21}$ M. Friedman, op.cit., s. 24.

22 F. Modigliani, R. Brumberg, Utility Analysis and the Consumption Function: An interpretation of Cross-Section Data, w: Post-Keynesian Economics, red. K. Kurihara, Rutgers University Press, New Brunswick 1954, s. 388-436.

${ }^{23}$ F. Modigliani, A. Ando, The Life Cycle Hypothesis of Saving: Aggregate Implications and Tests, "American Economic Review" 1963, vol. 53, March, s. 55-84.

${ }^{24}$ Można tu znaleźć nawiązanie do kapitału ludzkiego.

${ }^{25}$ Obecne zmiany społeczno-ekonomiczne sprawiają jednak, że przychody w trakcie życia mają bardzo zróżnicowany przebieg.

26 Warto zauważyć, że mimo rozwoju rachunków narodowych i statystyki publicznej z utylitarnego punktu widzenia dane dotyczące przepływów (takich jak przychody) są łatwiejsze do uzyskania niż aktywów.

${ }^{27}$ Może to nastąpić przez użycie odwróconej hipoteki albo umowy dożywocia. 
Hipoteza cykli życia z uwagi na okres powstania odnosi się do bardzo ogólnych kategorii. Na przykład skutki zadłużenia odnotowuje się w dwóch miejscach. Odsetki (koszt zadłużenia) zawierają się w wydatkach konsumpcyjnych obok wydatków bieżących na dobra nietrwałe i na odtworzenie dóbr trwałych. Natomiast spłata zadłużenia (raty kapitałowe) zwiększa zasoby na równi z oszczędnościami. Przyszłe zobowiązania powinny być zatem ujęte w zasobach jako część przyszłych przychodów, co oznacza w pewnym sensie zmniejszenie możliwości sfinansowania konsumpcji z bieżących przychodów przez „przymusowe” oszczędności. Podobny charakter mają składki na zabezpieczenie emerytalne, które tworzą swego rodzaju zasoby emerytalne. F. Modigliani zrezygnował z wprowadzenia niepewności do modelu, tym samym model ten nie uwzględnia losowych wahan przychodów i zasobów, np. na skutek zniszczenia zasobów mieszkaniowych. Jednak już samo posługiwanie się strumieniami konsumpcji i przychodów oraz możliwość wykorzystania zasobów jest bardzo istotną zaletą pozwalającą na określenie potencjalnych skutków finansowych częściowej albo całkowitej utraty zasobów.

W latach 70. modele funkcji konsumpcji stworzone w latach 50. poddane zostały krytyce. R. Lucas twierdził, że nie jest możliwe określenie stałej relacji konsumpcji do przychodów, funkcja konsumpcji potwierdza relacje między faktycznym i permanentnym przychodem, ale nie są one stabilne. Według Lucasa nie można na podstawie przeszłych i obecnych danych wyznaczyć stałego parametru określającego przyszłe przychody ${ }^{28}$. W odpowiedzi na krytykę R. Hall zaproponował hipotezę losowego błądzenia (random-walk), która opierając się na równaniu Eulera zakłada, że bieżąca konsumpcja jest uzależniona jedynie od konsumpcji z wcześniejszego okresu i ma charakter stochastyczny ${ }^{29}$. Tym samym Hall zakłada, że wszystkie właściwe informacje dotyczące przyszłych przychodów zostały uwzględnione w przeszłych poziomach konsumpcji. Dlatego tylko nieprzewidziane zdarzenia będą miały wpływ na konsumpcję.

Mimo powszechnej akceptacji koncepcji cykli życia i permanentnego przychodu oraz wykorzystania jej w realizacji polityki publicznej, odnotowano wiele przykładów, w których hipoteza ta się nie sprawdza ${ }^{30}$. Na szczególne podkreślenie zasługuje tutaj praca I.Y. Campbella oraz N.G. Mankiwa ${ }^{31}$. Zbadali oni na podstawie danych

28 R.E. Lucas, Econometric Policy Evaluation: A Critique, "Carnegie-Rochester Series on Public Policy" 1976, vol. 1, red. K. Brunner, A.H. Meltzer, North-Holland, Amsterdam.

${ }^{29}$ R. Hall, Stochastic Implication of the Life Cycle-Permanent Income Hypothesis: Theory and Evidence, "Journal of Political Economy" 1978, vol. 86, no. 6.

${ }^{30} \mathrm{Na}$ odrębny komentarz zasługuje wpływ formalnego zapisu hipotez ekonomicznych na ich operacjonalność, tj. testowalność oraz praktyczne wykorzystanie. Operacjonalność wymuszała częstokroć formułowanie założeń, które stoją w sprzeczności z charakterem wyjaśnianych zjawisk.

${ }^{31}$ J.Y. Campbell, G. Mankiw, Consumption, Income and Interest Rates: Reinterpreting the Time-Series Evidence, "NBER Macroeconomic Annual" 1989. 
empirycznych, na ile konsumenci amerykańscy stosują w jakimś stopniu planowanie konsumpcji, tzn. przeszła konsumpcja pozwala im prognozować przyszłe przychody, a w jakim stopniu uzależniają bieżącą konsumpcję od bieżących przychodów. Wyniki pokazały, że około połowie konsumentów można przypisać znamiona planowania konsumpcji w odniesieniu do przyszłych spodziewanych przychodów. Wspomniani autorzy dowiedli również, że wbrew modelom Friedmana oraz Modiglianiego i Brumberga, stopa procentowa nie wpływa na zmianę poziomu konsumpcji (kosztu międzyokresowej substytucji konsumpcji) ${ }^{32}$. Również faktyczny poziom oszczędności gospodarstw domowych okazał się być odmienny od modelu hipotezy cykli życia ${ }^{33}$. Dodatkowo na danych przekrojowych wykazano, że oszczędności są pozytywnie powiązane z sumą przychodów w trakcie trwania życia ${ }^{34}$. Ponadto duża część zasobów jest dziedziczona, dla przeciętnego permanentnego przychodu z każdego dolara aktywów rodziców około 2,5 centa podlega dziedziczeniu. Ta zależność jest tym silniejsza, im wyższe są przychody rodziców ${ }^{35}$.

Hipoteza cykli życia nie dała też wytłumaczenia dla wzrostu relacji konsumpcji do przychodów w latach 1981-2011, ponieważ nie wystąpił wówczas „oczekiwany” przyrost przychodów (wynikający z produktywności pracy), nie zwiększyły się również w takim stopniu zasoby (w związku ze wzrostem wartości aktywów gospodarstw domowych ${ }^{36}$. Natomiast całkiem racjonalne wytłumaczenie zjawiska zwiększenia zadłużenia gospodarstw domowych wskutek obniżenia stóp procentowych nie jest zgodne z pierwotną hipotezą cykli życia ${ }^{37}$. W myśl tej hipotezy użycie oszczędności oraz długu ma na celu wygładzenie konsumpcji. Natomiast wzrost zadłużenia wystąpił głównie w gospodarstwach domowych o niskich przychodach (poniżej 50 tys. USD) i osiągnął poziom 298\% (relacja dług do przychodów) ${ }^{38}$, który trudno uznać za służący do wygładzenia konsumpcji ${ }^{39}$.

32 Tzn. że np. zwiększenie stopy procentowej nie wpłynie na zwiększenie oszczędności kosztem konsumpcji.

${ }^{33}$ B.B. White, Empirical Tests of the Life Cycle Hypothesis, "American Economic Review" 1978, vol. 68, no. 4.

${ }^{34}$ M. Browning, A. Lusardi, Household saving: micro facts and micro theories, "Journal of Economic Literature" 1996, vol. 34, no. 4, s. 1797-1855; K. Dynan, J. Skinner, S.P. Zeldes, Do the rich save more, "Journal of Political Economy" 2004, vol. 112, no. 2, s. 397-444.

${ }^{35}$ J.G. Altonji, E. Villanueva, The Marginal Propensity to Spend on Adult Children, "The B.E. Journal of Economic Analysis and Policy" 2007, vol. 7, no. 1.

36 J.A. Parker, Spendthrift in America? On Two decades of Decline in the U.S. Savings Rate, "NBER Macroeconomic Annual" 2000, red. B.S. Bernake, J.J. Rotemberg; A.B. Kennickell, Ponds and Streams: Wealth and Income in the U.S., 1989 to 2007, "Federal Reserve Board Working Paper" 2009.

37 I.T. Palley, Economic contradictions coming home to roost? Does the U.S. economy face a long-term aggregate demand generation problem?, "Journal of Post Keynesian Economics" 2002, vol. 25, no. 1, Fall.

${ }^{38} \mathrm{Nie}$ wspominając, że dotyczyło to około $2 / 3$ gospodarstw domowych. Ibidem.

${ }^{39}$ C. Fazzari, Household Debt in the Consumer Age: Source of Growth - Risk of Collapse, "Capitalism and Society" 2008, vol. 3, no. 2. 
Ponadto, począwszy od kryzysu finansowego, zadłużenie gospodarstw domowych w Stanach Zjednoczonych gwałtownie spadło. W tym kontekście należy zauważyć, że początkowo dane empiryczne wskazywały na mniejszą niż optymalna wielkość długu w pierwszej fazie życia, co tłumaczono istnieniem ograniczeń w zaciąganiu zobowiązań (liquidity constraints) ${ }^{40}$. Ale obecnie zadłużenie z tytułu kredytów studenckich (1,16 trylionów USD - 4kw. 2014) w Stanach Zjednoczonych przekroczyło zadłużenie z tytułu kart kredytowych (0,70 trylionów USD - 4 kw. 2014) i kredytów samochodowych (0,95 trylionów USD - 4 kw. 2014) $)^{41}$. Oznacza to, że zaszła diametralna zmiana w dostępie do kredytów dla osób młodych w pierwszym etapie.

Bardzo problematyczny jest również okres emerytalny. Po pierwsze, oszczędności emerytalne, które stanowić mają główny motyw odraczania konsumpcji są zbyt małe. Po drugie, następuje tutaj większe niż wskazywałaby hipoteza cykli życia obniżenie konsumpcji. Po trzecie, dekumulacja w większości wypadków nie obejmuje zasobów mieszkaniowych i jest powolniejsza niż wynikałoby to z pierwotnej hipotezy cykli życia ${ }^{42}$. Po czwarte, powyższym wspomnianym trendom towarzyszą bardzo duże różnice w zależności od poziomu przeszłych przychodów i zasobów oraz poziomu wykształcenia ${ }^{43}$.

W odpowiedzi na uzasadnioną krytykę modeli cykli życia coraz częściej mówi się o schemacie cykli życia, który oznacza międzyokresową alokację czasu, wysiłków i pieniędzy. I jako taka konstrukcja schemat ten jest wciąż interesującą koncepcją. Na jej podstawie tworzone są różne modele cykli życia, natomiast nie istnieje jeden obowiązujący model ${ }^{44}$. Większość krytyki dotyczyła pierwszych modeli cykli życia i przyczyniła się do powstania bardziej zaawansowanych modeli, które pozostają w nurcie schematu cykli życia. Uwzględnienie ograniczonej racjonalności (bounded rationality $)^{45}$, lepsze zrozumienie relacji stopy procentowej i konsumpcji ${ }^{46}$, wpływu systemu zabezpieczenia społecznego na zachowania gospodarstw domowych w trakcie

${ }^{40} \mathrm{~L}$. Thurow, The optimum lifetime distribution of consumption expenditures, "American Economic Review" 1969, no. 59, s. 324-330.

${ }^{41}$ The Federal Reserve Bank of New York Consumer Credit Panel/Equifax.

${ }^{42}$ Opóźnienie dekumulacji można uzasadnić poprzez wprowadzenie niepewności co do dalszego trwania życia.

${ }^{43}$ M. Browning, A. Lusardi, Household saving: micro facts and micro theories, "Journal of Economic Literature" 1996, vol. 34, no. 4, s. 1839-1846.

${ }^{44}$ M. Browning, T.F. Crossley, The Life-Cycle Model of Consumption and Savings, "Journal of Economic Perspectives" 2001, vol. 15, no. 3, s. 3; M. Browning, A. Lusardi, op.cit., s. 1800.

${ }_{45}$ M. Browning, D. Collado, The Response of Expenditures to Anticipated Income Changes: Panel Data Estimates, "American Economic Review" 2001, vol. 91, no. 3, s. 681-692.

${ }^{46}$ J. Parker, The Reaction of Household Consumption to Predictable Changes in Payroll Tax Rates, "American Economic Review" 1999, vol. 89, no. 4, s. 959-73; C. Hsieh, Do Consumers React to Anticipated Income Shocks? Evidence from the Alaska Permanent Fund, Mimeo, Princeton 2000. 
spadku przychodów z pracy ${ }^{47}$ oraz wpływu posiadania dzieci na kształt krzywej konsumpcji ${ }^{48}$ sprawia, że zdolność nowych modeli cykli życia do objaśnienia zachowań gospodarstw domowych zdaje się być coraz lepsza.

Jednocześnie pojawia się wiele propozycji, które zmieniając podstawowe założenia, istotnie wprowadzają bardzo ciekawe wątki do koncepcji cykli życia. R. Thaler inspirowany jej krytyką, a szczególnie faktem, że konsumpcja jest bardzo wrażliwa na przychody oraz niedoskonałą substytucją różnych rodzajów zasobów, zakwestionował jedno z podstawowych założeń, tj. wymienność różnych form przychodów i zasobó $w^{49}$. Thaler wyszedł z założenia, że gospodarstwa domowe tworzą swoiste konta mentalne, którym przyporządkowują różne przychody i zasoby, różniące się marginalną skłonnością do konsumpcji. Wyodrębnił bieżące przychody, zasoby oraz przyszłe przychody, a marginalna skłonność do konsumpcji dla poszczególnych pozycji wynosi odpowiednio wartość bliską jedności, wartość między zerem i jednością oraz wartość bliską zeru.

Według Thalera bieżąca konsumpcja jest w bardzo dużym stopniu uzależniona od bieżących przychodów. Spadki przychodów, wynikające chociażby z utraty pracy, będą w dużym stopniu prowadzić do korekty konsumpcji. Badania empiryczne pokazały, że ludzie w niewielkim stopniu dostosowują konsumpcję nawet do pewnych przyszłych dochodów, jak np. waloryzacja świadczeń. Wzrost konsumpcji następuje dopiero po otrzymaniu wyższego świadczenia ${ }^{50}$. Niewielkie dodatkowe ponadstandardowe przychody są przeznaczane na bieżącą konsumpcję $e^{51}$, ale już większe częściej zasilają zasoby $^{52}$, z których finansowane są dobra trwałe i tylko w wypadku krytycznych sytuacji wykorzystywane są na potrzeby konsumpcyjne ${ }^{53}$.

${ }^{47}$ M. Browning, T.F. Crossley, op.cit., s. 11.

${ }^{48}$ M. Browning, M. Ejrnaes, Consumption and Children, Mimeo, University of Copenhagen, 2000.

${ }_{49}$ R.H. Thaler, Anomalies: Saving, Fungibility, and Mental Accounts, "The Journal of Economic Perspectives" 1990, vol. 4, no. 1, s. 193-205.

${ }^{50}$ D.W. Wilcox, Social Security Benefits, Consumption Expenditure, and the Life Cycle Hypothesis, "Journal of Political Economy" 1989, vol. 97, no. 2, s. 288-304.

${ }^{51}$ Chociaż tutaj również zależy, w jakiej formie występuje dodatkowy przychód. Jeżeli jest to niezrealizowane zwiększenie wartości zasobów (np. posiadanych akcji), wówczas traktowane jest jako zwiększenie zasobów z marginalną skłonnością do konsumpcji bliską zeru. Natomiast zrealizowane niewielkie zyski, w postaci łatwo dostępnej gotówki, z większym prawdopodobieństwem zostaną przeznaczone na konsumpcję. G.N. Hatsopoulos, P.R. Krugman, J.M. Poterba, Overconsumption: The Challenge to U.S. Economic Policy, "American Business Conference" 1989, za: R.H. Thaler, Anomalies: Saving, Fungibility, and Mental Accounts, "The Journal of Economic Perspectives" 1990, vol. 4, no. 1, s. 197-198.

52 M. Landsberger, Windfall Income and Consumption: Comment, "American Economic Review" 1966, vol. 56, s. 534-539.

${ }_{53}$ B. Balassa, M. Noland, Japan in the World Economy, Institute for International Economics, Washington 1988 , s. $84-86$. 
Ponadto, są specyficzne rodzaje zasobów, które nie są traktowane wymiennie ${ }^{54}$. To np. zasoby mieszkaniowe, które bardzo rzadko są przedmiotem odwróconej hipoteki. A z kolei fakt istnienia oszczędności emerytalnych nie oznacza, że pozostałe oszczędności są większe. Częstokroć jest wręcz przeciwnie, osoby o podobnych przychodach, które posiadają oszczędności emerytalne, dysponują również większymi pozostałymi oszczędnościami.

Jedną z ważniejszych ewolucji w modelach cykli życia dokonano przez włączenie elementu niepewności. Nawet niewielki poziom niepewności może wpłynąć na ograniczenie skłonności do zadłużenia i zwiększenia stopy dyskonta przyszłych przychodów. Jednym z efektów wprowadzenia niepewności do modeli cykli życia jest istotny spadek wartości oczekiwanej zasobów. Ten spadek jest na tyle duży, że uzasadnia wprowadzenie ubezpieczeń (społecznych), które znacząco podnoszą ich wartość oczekiwaną ${ }^{55}$. Z kolei wprowadzenie ubezpieczeń wpływa istotnie na zmniejszenie skłonności do oszczędzania. Wciąż jednak nie uwzględnia się w sposób satysfakcjonujący możliwości i skutków zastosowania ubezpieczenia w modelach cykli życia ${ }^{56}$.

Gospodarstwa domowe organizują się w różny sposób. Mimo wciąż dominującej formy małżeństwa, należy zwrócić uwagę na zwiększającą się różnorodność, która przejawia się również zróżnicowaniem stosunków majątkowych w gospodarstwie domowym. Wśród dominujących form można wymienić małżeństwa z dziećmi, konkubinaty z dziećmi, małżeństwa bezdzietne, konkubinaty bez dzieci oraz osoby samotne. Dodatkowo w każdej z powyższych grup można wskazać osoby, które są rozwiedzione albo owdowiały. W drugiej połowie XX w. rozwinął się obszar badań relacji między członkami gospodarstw domowych i ich aktywnością ekonomiczną oraz później stosunków ekonomicznych. Zauważono istotne różnice między ogólną aktywnością ekonomiczną poszczególnych form, jak również próbowano określić ich ekonomiczną efektywność, wychodząc poza tradycyjny zestaw dóbr rynkowych i ich użyteczność.

W mikroekonomicznym nurcie badań nad gospodarstwem domowym w kontekście finansów osobistych należy przede wszystkim zwrócić uwagę na preferencje oraz sposób podejmowania decyzji ekonomicznych, charakterystyki różnych form gospodarstw domowych, jak również osiąganie poszczególnych etapów edukacji i posiadanie dzieci. W ekonomii neoklasycznej wciąż dominuje model „unitarny” gospodarstwa domowego, który zakłada traktowanie go jako niepodzielnej jedności, decyzje są podejmowane wspólnie, tak aby maksymalizować określony zestaw

${ }^{54}$ R.H. Thaler, Anomalies: Saving, Fungibility, and Mental Accounts, "The Journal of Economic Perspectives" 1990, vol. 4, no. 1, s. 198-202.

${ }^{55}$ Przy założeniu niezależności zdarzeń.

${ }^{56}$ M. Browning, A. Lusardi, op.cit., s. 1801-1804. 
celów, wspólny dla wszystkich ${ }^{57}$. Wszystkie zasoby gospodarstwa domowego służą do zapewnienia potrzeb jego członków. Członkowie takiego gospodarstwa domowego posiadają takie same preferencje i takie same krzywe użyteczności. Zasadniczo wskazuje się na trzy sytuacje, gdy preferencje są takie same, tj.: dyktatura, altruizm oraz wspólnota preferencji ${ }^{58}$.

Jednak coraz częściej model „unitarny” (unitary model) uznaje się za nieadekwatny zarówno z punktu widzenia teoretycznego, jak i praktycznego ${ }^{59}$. Po pierwsze, bardzo restrykcyjne założenia modelu nie odzwierciedlają faktycznych relacji w gospodarstwie domowym. Po drugie, nie pozwalają na skuteczne prowadzenie polityki skierowanej do gospodarstw domowych, gdyż wielokrotnie model ten się nie sprawdzał z uwagi na brak różnicowania adresatów określonych działań.

Obecnie coraz częściej używa się modelu kolektywnego (collective model), który zakłada i uwzględnia indywidualność poszczególnych członków gospodarstwa domowego. W ramach modelu kolektywnego wyróżnia się dwa typy - kooperacyjny i niekooperacyjny. Typ niekooperacyjny (noncooperative type) zakłada, że ludzie nie są w stanie związać się długoterminowymi kontraktami, aczkolwiek zachowania jednostek są uwarunkowane działaniami podejmowanymi przez innych. Typ kooperacyjny (cooperative type) charakteryzuje się tym, że decyzja o stworzeniu gospodarstwa domowego (innego niż jednoosobowe) jest uzależniona od poziomu użyteczności. Dodatkowe korzyści są rozdysponowywane na członków gospodarstwa domowego.

W typie kooperacyjnym wyróżnia się dwie subklasy modeli. Modele pierwszej kategorii zakładają, że decyzje gospodarstwa domowego są zawsze efektywne w sensie Pareto, bez narzucania odgórnie charakteru procesu decyzyjnego albo umiejscowienia efektu końcowego ${ }^{60}$. Modele drugiej kategorii zakładają, że proces decyzyjny w gospodarstwie domowym jest oparty na „negocjacjach”. Wówczas podział przychodów/korzyści może być modelowany wg wyniku akceptowalnego (fallback) albo osiąganego bez włączenia się w interakcje (threat point) dla każdego z członków. Najczęściej modele „negocjacyjne” opierają się na równowadze Nasha.

57 F. Ellis, Peasant Economics, Farm Household and Agrarian Development, Cambridge University Press, Newcastle 1988.

58 Pierwsza sytuacja związana jest z przemocą, coraz częściej ekonomiczną. Wówczas dochodzi do wypaczenia faktycznych preferencji i potrzeb gospodarstwa domowego. Druga sytuacja zakłada altruistyczne podejście każdego z członków gospodarstwa domowego i podejmowanie decyzji jedynie w kontekście wspólnego dobra. Trzecia sytuacja sprowadza się do zagregowania indywidualnych funkcji użyteczności z predefiniowaną wagą.

59 P.A. Chiappori, L. Haddad, J. Hoddinott, R. Kanbur, Unitary versus collective models of the household: time to shift the burden of proof?, Policy Research Working Paper 1217, vol. 1, The World Bank, Ghana Resident Mission, November 1993.

${ }^{60}$ Zakłada się możliwość istnienia kilku maksimów lokalnych. 


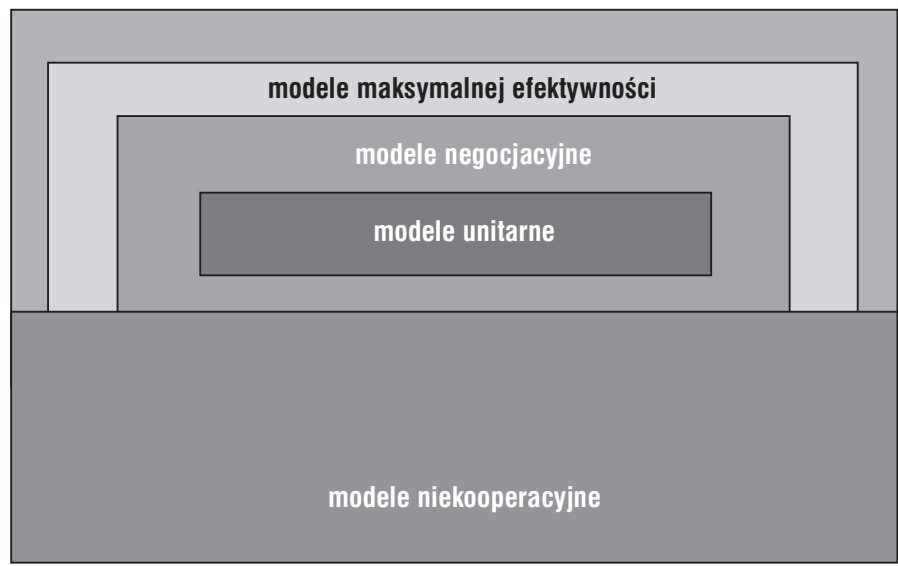

\section{Schemat 1. Modele gospodarstw domowych w ujęciu mikroekonomicznym}

Źródło: P.A. Chiappori, L. Haddad, J. Hoddinott, R. Kanbur, Unitary versus collective models of the household: time to shift the burden of proof?, Policy Research Working Paper 1217, vol. 1, The World Bank, Ghana Resident Mission, November 1993, s. 10.

W oczywisty sposób cechy charakterystyczne modelu wpływają na decyzje finansowe gospodarstw domowych oraz skuteczność określonych narzędzi polityki publicznej. Potwierdzenie istnienia poszczególnych modeli można znaleźć w wynikach badań psychologicznych, analizujących relacje między członkami gospodarstwa domowego w kontekście podejmowania decyzji o charakterze finansowym. Badania te zasadniczo zapoczątkowano w latach 80 . XX w. i dotyczyły one małżeństw, a w późniejszym okresie również związków kohabitacyjnych ${ }^{61}$. Pozycja ekonomiczna poszczególnych członków gospodarstwa domowego wynika m.in. z modelu małżeństwa. W tym kontekście szczególnie podkreśla się konsekwencje modelu patriarchalnego, tj. zależność finansową kobiet i dzieci. Jednak z czasem małżeństwa stały się coraz bardziej egalitarne i symetryczne, co skutkowało zmianami w prawie rodzinnym ${ }^{62}$ oraz systemie zabezpieczenia społecznego ${ }^{63}$.

${ }^{61}$ Gwoli ścisłości należy wspomnieć, że to socjolodzy w latach 70. XX w. po raz pierwszy wyodrębnili pojęcie „jej małżeństwo” i ,jego małżeństwo” dla podkreślenia odmiennych oczekiwań oraz bardzo czasami różnego odbierania małżeństwa przez kobiety i mężczyzn, co może wynikać m.in. z różnej pozycji ekonomicznej. J.B. Jessie, The Future of Marriage, Yale University Press, New Haven 1972, s. 20.

62 Należy pamiętać, że zmiany w prawie rodzinnym są inicjowane przez zmiany społeczne, ale również sama zmiana prawa rodzinnego może wzmocnić pierwotne tendencje.

${ }^{63}$ Model, w którym mężczyzna w głównej mierze koncentruje się na pracy zarobkowej, a kobieta na niezarobkowej, może być również przejawem działań optymalizacyjnych, gdyż specjalizacja pozwala na uzyskanie większych przychodów. Efekt ten, wyższe zarobki mężczyzn, wyraźnie zaobserwowano w małżeństwach, co można również tłumaczyć wyższymi kompetencjami zawodowymi mężczyzn, którzy wstępują w związki małżeńskie w porównaniu z tymi, którzy pozostają w związkach kohabitacyjnych lub są singlami. J. Baxter, E. Gray, For Richer and Poorer: Women, Men and Marriage, Negotiating the Life Course Discussion paper Series, Discussion paper DP-012, Centre for Social Research, Australian 
W ekonomii często zakłada się, że członkowie gospodarstwa domowego żyją na podobnym poziomie. Co nie zawsze jest słusznym założeniem i w dużym stopniu zależy od dysponowania i podziału środków. Na podstawie badań nad małżeństwami heteroseksualnymi wyróżniono następujące modele związków:

- model zarządzania przez kobietę (the female whole wage system) - mężczyzna przekazuje całe wynagrodzenie żonie (przeważnie po odjęciu osobistych wydatków), a kobieta używa tych pieniędzy, powiększonych ewentualnie o własne przychody, na sfinansowanie potrzeb całego gospodarstwa domowego,

- model zarządzania przez mężczyznę (the male whole wage system) - mężczyzna bierze na siebie całą odpowiedzialność za finanse gospodarstwa domowego, co może niezarabiające kobiety pozostawić bez środków na osobiste wydatki.

- model zaopatrzeniowy (the allowance system) - mężczyzna przekazuje stałą sumę na wydatki, pozostawiając resztę środków do własnej dyspozycji,

- model wspólnych zasobów (the pooling system) - partner i partnerka przekazują do wspólnego funduszu wszystkie albo prawie wszystkie środki,

- model częściowo wspólnych zasobów (the pooling system) - partner i partnerka przekazują do wspólnego funduszu część środków,

- model niezależnego zarządzania (the independent management system - IM) - partner i partnerka mają swoje odrębne, osobiste przychody i przechowują je na oddzielnych kontach ${ }^{64}$.

Pierwsze trzy modele wraz ze zmianami społecznymi (takimi jak wzrost aktywności zawodowej kobiet, opóźnianie momentu narodzin dziecka i częstszy po nim powrót na rynek pracy) straciły na znaczeniu i obecnie przeważają modele wspólnych oraz częściowo wspólnych zasobów czy niezależnego zarządzania. Modele wspólnych i częściowo wspólnych zasobów są stosowane przez największy odsetek małżeństw oraz związków partnerskich, głównie za sprawą czynników redukujących udział gospodarstw z jednym żywicielem (tj. zwiększonej aktywności zawodowej kobiet), a także zmianom norm społecznych (tj. wspomnianego egalitaryzmu i symetryczności) ${ }^{65}$. Istotnym czynnikiem zwiększającym odsetek związków, które można zidentyfikować jako przedstawicieli modelu częściowo wspólnych zasobów jest postępująca indywidualizacja. Natomiast model niezależnego zarządzania nabiera szczególnego

\footnotetext{
National University, April 2003. Wyższym zarobkom mężczyzn towarzyszy jednakowoż pogorszenie się statusu kobiet na rynku pracy.

${ }^{64} \mathrm{~J}$. Pahl, His money, her money: recent research on financial organisation in marriage, "Journal of Economic Psychology" 1995, vol. 16, s. 361-376; J. Pahl, Individualisation in couple finances: who pays for the children?, "Social Policy and Society" 2005, vol. 4, s. 381-391; C.B. Burgoyne, V. Clarke, J. Reibstein, A.E. Edmunds, All my worldly goods I share with you? Managing money at the transition to heterosexual marriage, "The Sociological Review" 2006, vol. 54, s. 619-637.

$65 \mathrm{~J}$. Pahl, Individualisation in couple finances..., op.cit.
} 
znaczenia głównie za sprawą zwiększonego udziału osób posiadających partnerów, ale nie żyjących z nimi na stałe (living apart together), związków partnerskich i małżeństw z udziałem osób rozwiedzionych.

Przypisanie konkretnych modeli do poszczególnych gospodarstw domowych służy identyfikacji sposobu zarządzania finansami gospodarstw domowych i jego wpływu na dobrostan każdego z członków. Należy wyróżnić bieżące zarządzanie środkami finansowymi oraz sprawowanie kontroli nad strukturą i wielkością wydatków. Pełna ocena wymaga jednoczesnego uwzględnienia czynników obiektywnych (tj. posiadanie oddzielnych kont lub bieżące zarządzanie) oraz subiektywnych (tj. sposób podejmowania decyzji, zakres autonomii oraz kontroli) ${ }^{66}$. Jednak stosowane kryteria nie zapewniają jednoznacznego podziału. W badaniach empirycznych często napotykano problem dopasowania poszczególnego gospodarstwa domowego do jednego modelu, a samoocena może się różnić od oceny eksperckiej ${ }^{67}$.

W przedstawionych koncepcjach dotyczących funkcjonowania gospodarstw domowych widać bardzo wyraźnie znaczenie finansów gospodarstw domowych dla całej gospodarki. Nurt makroekonomiczny, analizując relacje przychodów i konsumpcji, próbuje przewidzieć przyszłe zachowania gospodarstw domowych, jak również szuka nowych sposobów wpływania na gospodarstwa domowe.

Bardzo ważnym elementem tych rozważań jest model cykli życia, który określa perspektywę analizy finansów, a jego koncepcja może zostać użyta do optymalizacji wydatków w czasie i planowania finansowego. Nieustanna weryfikacja kolejnych wersji modeli cykli życia istotnie wzbogaciła naszą wiedzę o zachowaniach gospodarstw domowych w kolejnych fazach cykli życia. Określenie zakresu wymienności różnych form przychodów i zasobów w kontekście decyzji o konsumpcji albo oszczędności oraz uwzględnienie niepewności zbliżyło tworzone modele do rzeczywistości.

W nurcie mikroekonomicznym wiele badań dotyczy maksymalizacji użyteczności zachowań w kontekście sposobu podejmowania decyzji. Wraz z rozwojem tej dziedziny nastąpiły również rozwój i multiplikacja modeli podejmowania decyzji w gospodarstwach domowych, od modelu unitarnego do modeli negocjacyjnych.

Teorie socjologiczne wykazały dualizm w postrzeganiu małżeństwa i związków w kontekście oczekiwań w zależności od płci. Natomiast teorie psychologiczne, analizując modele zarządzania finansami gospodarstw domowych, skojarzyły je

${ }^{66}$ K.J. Ashby, C.B. Burgoyne, Separate financial entities? Beyond categories of money management, “The Journal of Socio-Economics," 2008, vol. 37, s. 460. Czynniki subiektywne mogą istotnie wpłynąć na faktyczną realizację wspomnianej idei egalitaryzmu.

67 S.J. Sonnenberg, Household financial organisation and discursive practice: managing money and identity, "Journal of Socio-Economics" 2008, vol. 37, s. 533-551. 
z rodzajami związków, co ma niebagatelne znaczenie dla identyfikacji możliwości i potrzeb poszczególnych gospodarstw domowych.

Przegląd teorii, niezależnie od dziedziny nauki, pokazuje na postępujący wzrost złożoności oraz indywidualizacji finansów gospodarstw domowych. Nie oznacza to bynajmniej zmniejszenia roli polityki publicznej w zakresie zapewnienia bezpieczeństwa ekonomicznego gospodarstw domowych. Wręcz przeciwnie, rosnąca finansjalizacja budżetów gospodarstw domowych stawia przed polityką publiczną nowe wyzwania. Dla osiągnięcia założonego poziomu skuteczności wymagana jest większa precyzja w konstrukcji rozwiązań publicznych.

\section{Bibliografia}

Akerlof A., Kranton R.E., Economics and identity, "The Quarterly Journal of Economics" 2000, vol. CXV, no. 3.

Altonji J.G., Villanueva E., The Marginal Propensity to Spend on Adult Children, "The B.E. Journal of Economic Analysis and Policy" 2007, vol. 7, no. 1.

Ando A., Modigliani F., The "Life Cycle" Hypothesis of Saving: Aggregate Implications and Tests, "American Economic Review" 1963, vol. 53, no. 1.

Ashby K.J., Burgoyne C.B., Separate financial entities? Beyond categories of money management, "The Journal of Socio-Economics" 2008, vol. 37.

Balassa B., Noland M., Japan in the World Economy, Institute for International Economics, Washington 1988.

Baxter J., Gray E., For Richer and Poorer: Women, Men and Marriage, Negotiating the Life Course Discussion paper Series, Discussion paper DP-012, Centre for Social Research, Australian National University, April 2003.

Browning M., Collado D., The Response of Expenditures to Anticipated Income Changes: Panel Data Estimates, "American Economic Review" 2001, vol. 91, no. 3.

Browning M., Crossley T.F., The Life-Cycle Model of Consumption and Savings, "Journal of Economic Perspectives" 2001, vol. 15, no. 3.

Browning M., Ejrnaes M., Consumption and Children, Mimeo, University of Copenhagen, 2000.

Browning M., Lusardi A., Household saving: micro facts and micro theories, "Journal of Economic Literature" 1996, vol. 34, no. 4.

Burgoyne C.B., Clarke V., Reibstein J., Edmunds A.E., All my worldly goods I share with you? Managing money at the transition to heterosexual marriage, "The Sociological Review" 2006, vol. 54 .

Chiappori P.A., Haddad L., Hoddinott J., Kanbur R., Unitary versus collective models of the household: time to shift the burden of proof?, Policy Research Working Paper 1217, vol. 1, The World Bank, Ghana Resident Mission, November 1993. 
Bywalec Cz., Ekonomia i finanse gospodarstw domowych, Wydawnictwo Naukowe PWN, Warszawa 2012.

Campbell J.Y., Mankiw G., Consumption, Income and Interest Rates: Reinterpreting the Time-Series Evidence, "NBER Macroeconomic Annual” 1989.

Cynamon B.Z., Fazzari S.M., Household Debt in the Consumer Age: Source of Growth - Risk of J. Duesenberry, Income, Saving and the Theory of Consumption Behavior, Harvard University Press, Cambridge 1949.

Duesenberry J., Income, Saving and the Theory of Consumption Behavior, Harvard University Press, Cambridge 1949.

Dynan K., Skinner J., Zeldes S.P., Do the rich save more, "Journal of Political Economy" 2004, vol. 112 , no. 2.

Ellis F., Peasant Economics, Farm Household and Agrarian Development, Cambridge University Press, Newcastle 1988.

Friedman M., A Theory of the Consumption Function, Princeton University Press, New Jersey 1957.

Fisher I., The rate of interest. Its nature, determination and relations to economic phenomena, The MacMillian Company, New York 1907.

Fuhrer J.C., Habit Formation in Consumption and Its Implications for Monetary-Policy Models, "American Economic Review" 2000, vol. 90, no. 3.

Goldsmith R.W., A study on saving in the United States, Princeton University Press, New Jersey 1955.

Hall R., Stochastic Implication of the Life Cycle-Permanent Income Hypothesis: Theory and Evidence, "Journal of Political Economy" 1978, vol. 86, no. 6.

Hatsopoulos G.N., Krugman P.R., Poterba J.M., Overconsumption: The Challenge to U.S. Economic Policy, American Business Conference, 1989.

Hsieh C., Do Consumers React to Anticipated Income Shocks? Evidence from the Alaska Permanent Fund, Mimeo, Princeton 2000.

Jessie J.B., The Future of Marriage, Yale University Press, New Haven 1972.

Kawiński M., Ubezpieczenie społeczne a finanse osobiste, Doubezpieczenie społeczne - idea i kontynuacja, red. M. Kawiński, Oficyna Wydawnicza SGH, Warszawa 2015.

Kennickell A.B., Ponds and Streams: Wealth and Income in the U.S., 1989 to 2007, Federal Reserve Board Working Paper 2009.

Keynes J.M., The General Theory of Employment, Interest and Money, Harcourt, Brace Company, New York 1937.

Kuznets S., Uses of National Income in Peace and War, NBER, March 1942.

Landsberger M., Windfall Income and Consumption: Comment, "American Economic Review" 1966, vol. 56.

Lucas R.E., Econometric Policy Evaluation: A Critique, "Carnegie-Rochester Series on Public Policy” 1976, vol. 1, red. K. Brunner, A.H. Meltzer, North-Holland, Amsterdam.

Modigliani F., Ando A., The Life Cycle Hypothesis of Saving: Aggregate Implications and Tests, "American Economic Review" 1963, vol. 53. 
Modigliani F., Brumberg R., Utility Analysis and the Consumption Function: An interpretation of Cross-Section Data, w: Post-Keynesian Economics, red. K. Kurihara, Rutgers University Press, New Brunswick 1954.

Osiński J., Wstęp, w: Polityka publiczna we współczesnym państwie, red. J. Osiński, Oficyna Wydawnicza SGH, Warszawa 2014.

Pahl J., His money, her money: recent research on financial organisation in marriage, "Journal of Economic Psychology” 1995, vol. 16.

Pahl J., Individualisation in couple finances: who pays for the children?, "Social Policy and Society" 2005, vol. 4.

Palley I.T., Economic contradictions coming home to roost? Does the U.S. economy face a long-term aggregate demand generation problem?, "Journal of Post Keynesian Economics" 2002, vol. 25, no. 1 .

Palley T.I., Relative Income and Consumption: A Synthesis of Keynes, Duesenberry, Friedman, and Modigliani and Brumbergh, July 2005.

Parker J., The Reaction of Household Consumption to Predictable Changes in Payroll Tax Rates, "American Economic Review" 1999, vol. 89, no. 4.

Parker J.A., Spendthrift in America? On Two decades of Decline in the U.S. Savings Rate, NBER Macroeconomic Annual 2000, red. B.S. Bernake, J.J. Rotemberg.

Ramsey F.P., A Mathematical Theory of Saving, “The Economic Journal” 1928, vol. 38, no. 152.

Sonnenberg S.J., Household financial organisation and discursive practice: managing money and identity, "Journal of Socio-Economics" 2008, vol. 37.

Thaler R.H., Anomalies: Saving, Fungibility, and Mental Accounts, “The Journal of Economic Perspectives" 1990, vol. 4, no. 1.

Thurow L., The optimum lifetime distribution of consumption expenditures, "American Economic Review" 1969, no. 59.

White B.B., Empirical Tests of the Life Cycle Hypothesis, "American Economic Review" 1978, vol. 68 , no. 4 .

Wilcox D.W., Social Security Benefits, Consumption Expenditure, and the Life Cycle Hypothesis, "Journal of Political Economy" 1989, vol. 97, no. 2. 